\title{
Small-scale Management of Secondary Forests in the Brazilian Atlantic Forest
}

\author{
Alfredo Celso Fantini ${ }^{1}\left(\mathbb{B}\right.$, Cristiano Schuch $^{2}$ (D), Alexandre Siminski ${ }^{3}$ (ㅇ), \\ Ilyas Siddique $^{1}$ (D) \\ ${ }^{1}$ Departamento de Fitotecnia, Universidade Federal de Santa Catarina, Florianópolis/SC, Brasil \\ ${ }^{2}$ Empresa de Pesquisa Agropecuária de Santa Catarina - Epagri, Florianópolis/SC, Brasil \\ ${ }^{3}$ Departamento de Agricultura, Biodiversidade e Florestas, Universidade Federal de Santa Catarina - UFSC, \\ Florianópolis/SC, Brasil
}

\begin{abstract}
Sustainable management of tropical and subtropical secondary forests for multiple purposes, including timber, may encourage farmers to promote regeneration of native forest. We studied the population structures and commercial timber production in two adjacent 33 years-old Brazilian Atlantic Forest stands: a 26 ha forest managed through enrichment with three fast-growing commercial timber species, and a 10 ha naturally regenerated unmanaged forest. The tree species presented basal area of $26.9 \mathrm{~m}^{2} \mathrm{ha}^{-1}$ and $23.8 \mathrm{~m}^{2} \mathrm{ha}^{-1}$ in the enriched and the unmanaged forest, respectively. Timber volume $(\mathrm{DBH} \geq 15 \mathrm{~cm})$ in the enriched forest was $104 \mathrm{~m}^{3} \mathrm{ha}^{-1}\left(3.7 \mathrm{~m}^{3} \mathrm{ha}^{-1}\right.$ year-1 rate of increment), $67 \%$ of which from the species planted in the enrichment process. The unmanaged forest presented $78.4 \mathrm{~m}^{3} \mathrm{ha}^{-1}$ of timber $\left(2.4 \mathrm{~m}^{3} \mathrm{ha}^{-1}\right.$ year rate of increment) ( $45 \%$ from the planted species). Timber volumes and DBH distributions of both stands suggest that selective harvesting could produce valuable timber now, while stimulating growth of the next cycle.
\end{abstract}

Keywords: swidden fallows, smallholder forestry, uneven-aged stands, second growth forests, fast-growing species. 


\section{INTRODUCTION}

The native vegetation of the Brazilian Atlantic forest originally covered approximately 1.5 million hectares (Metzger, 2009), with ecosystems very rich in biodiversity and with a high degree of endemism (Tabarelli et al., 2010). However, the expansion of agriculture and urbanization rapidly shrunk the forest to $12.5 \%$ of its original forest cover.

Most remnants of the Atlantic forest are small and isolated patches (Ribeiro et al., 2009) formed by secondary forests typical of fallows in this climate (Lira et al., 2012; Vibrans et al., 2012), a consequence of the swidden cultivation as a prevalent land use in the region until recently (Siminski et al., 2011; Schorn \& Galvão, 2006). In the last three decades, however, Brazil has experienced a clear decline of swidden cultivation (Adams et al., 2013; Pedroso-Junior et al., 2008; Fantini et al., 2017), a trend observed elsewhere (Mukul \& Herbohn, 2016; Padoch \& Pinedo-Vasquez, 2010; Van Vliet et al., 2012). In the Atlantic forest region, socioeconomic factors seem to be important drivers of the swidden cultivation decline, especially the lack of labor caused by the rural exodus of young people and the recent enforcement of legal restrictions in suppressing successional forests (Siminski et al., 2011). Environmental regulations drive many farmers to actively prevent native forest regeneration in fear of restrictions and fines, to use the land productively in the future (Fantini et al., 2017; Alarcon et al., 2011). In the State of Santa Catarina, there is an abandoned cropland in almost all farms, allowing the fallow vegetation to advance to later stages of succession (Vicente \& Fantini, 2014), reached around 20 years after abandonment. However, the most common alternative is the conversion of the land to pastures and to even-aged forests, formed almost exclusively with exotic species of the genus Pinus and Eucalyptus (Siminski \& Fantini, 2010), land uses that are not subjected to control by the environmental agencies. In the region of our study, there is at least one stand of planted forest in every farm. Therefore, greater attention should be paid to land management systems that encourage forest conservation through the sustainable use of resources from secondary forests. There are several native timber species typical of secondary forests of the region with potential for commercial management (Fantini \& Siminski, 2016; Coradin et al., 2011).
The management of Neotropical secondary forests for producing timber has proved to be advantageous. For example, silvicultural practices such as thinning at early ages of succession improved productivity and quality of the forest in Costa Rica (Guariguata, 1999), Brazil (Mesquita, 2000) and Trinidad (Finegan, 1992). We believe that the potential of secondary forests of the Brazilian Atlantic Forest for management aiming at improving timber production may be even higher given the extent of secondary forests in the region and the fact that at least small patches of such ecosystems exist on every small farm. Secondary forest management and native tree plantation are an important, largely unutilized resource for the large number of small farms in the Atlantic forest region. There is also an enormous potential for the management of the 12 million hectares of forests that Brazil agreed to restore by 2030 under the Bonn Challenge, a million hectares in the Atlantic Forest region.

There is not a policy to promote the sustainable logging of native species from secondary forests of the Atlantic Forest, partially due to the scarcity of data on the potential of fast-growing of native trees to produce timber. Most of the existing studies focus on the floristics and ecology of the local ecosystems. The few publications reporting studies on native species for timber production (Coradin et al., 2011; Carvalho, 2003) refer mainly to experimental plots of plantations at early ages. In this study, we aimed to understand the impact of enrichment planting and tending of planted seedlings on the forest structure (Density and Basal Area) and commercial timber volume of secondary forests by comparing an unmanaged and an enriched secondary forest. Our hypothesis was that enrichment planting and slashing of undesired, naturally regenerating species in the early years of subtropical Atlantic Rainforest succession enhances stand structure and productivity of promising native commercial timber species.

\section{MATERIALS AND METHODS}

\subsection{Study site}

The study was conducted in the municipality of Massaranduba ( $26^{\circ} 32^{\prime}$ S; $\left.49^{\circ} 01^{\prime} \mathrm{W}\right)$, state of Santa Catarina, southern Brazil (Figure 1). The original vegetation in the region was Dense Rainforest. The climate of the 


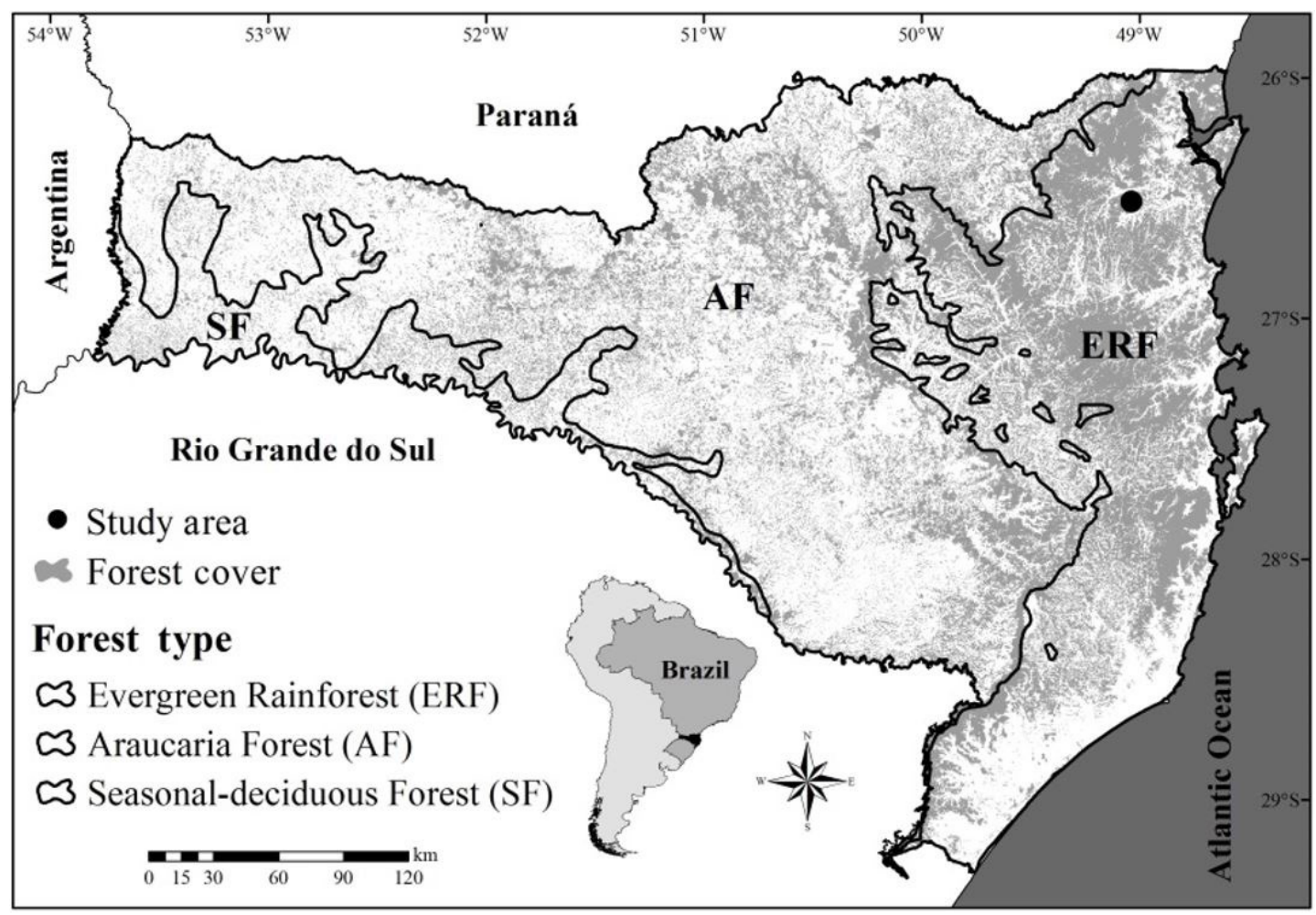

Figure 1. The forest cover (Fundação S.O.S. Mata Atlântica \& INPE 2014) and the main forest types (Klein 1980) of the state of Santa Catarina, and the location of the study area.

region is subtropical without a distinct dry season (Köppen: Cfa) with mean annual precipitation of 2,200 $\mathrm{mm}$. Soils in the region are predominantly Red Yellow Podzolic (mainly Ultisols) with low natural fertility, and slopes are mostly steep, up to $40 \%$.

The study area of 36 ha of secondary forest was previously an irregular mosaic of pastures and early successional forests, embedded in a large tract of forested land (> 5,000 ha) with both private and public ownership. Thirty-three years ago, 26 ha were enriched with seedlings of three common timber species from secondary forests of the region: jacatirão-açu (Miconia cinnamomifolia De Candolle), licurana (Hieronyma alchorneoides Allemão) and some species of canelas (Nectandra spp.). The records show that 924, 462 and 154 seedlings ha ${ }^{-1}$ of these species were planted, respectively, following an irregular spacing. During the first five years, the natural regeneration close to planted seedlings was slashed with a machete to reduce the density of non-commercial species; afterwards naturally regenerated plants were allowed to establish throughout the stand. All the information on silvicultural treatments was provided by the forest owner. We have no exact information on the intensity and frequency of this practice, for this study, the site was not subjected to the application of controlled experimental treatments. The remaining contiguous area (10 ha) of the same forest patch was abandoned without any planting, allowing the site to form a naturally regenerated secondary forest. Hereafter we name the areas enriched forest and unmanaged forest, respectively.

\subsection{Characteristics of the species planted in the enriched forest}

Hieronyma alchorneoides Allemão (Phyllanthaceae), locally known as licurana, is a fast-growing late secondary species that occurs from southern Brazil to Mexico. The species is dioecious, has zoophilic pollination syndrome and baroque and zoochoric dispersion (Carvalho, 2003). The wood is moderately heavy: 0.52 to $0.70 \mathrm{~g} \mathrm{~cm}^{-3}$, with heartwood reaching 0.74 to $0.85 \mathrm{~g} \mathrm{~cm}^{-3}$ (Wiemann, 2010). Piotto et al. (2003a) 
report an increment rate of $10 \mathrm{~m}^{3} \mathrm{ha}^{-1}$ year $^{-1}$. The bole of the trees is straight and its wood is highly resistant to decay in dry conditions and moderately to very durable upon contact with soil (Wiemann, 2010). The wood is used for several purposes, including heavy construction (interior and exterior), railway crossties, marine work, pole, flooring, furniture, decorative veneers, turnery, joinery (Wiemann, 2010; Coradin et al., 2011). After harvesting, the stump produces several sprouts, facilitating the regeneration of the species under management. The timber produces high quality charcoal.

Miconia cinnamomifolia (DC.) Naudin (Melastomataceae), locally known as jacatirão-açu, is also a fast-growing early secondary species from the Atlantic Forest region. The species is hermaphrodite, has zoophilic pollination syndrome and baroque and zoochoric dispersion, beginning the reproductive stage after 5 years of planting (Carvalho, 2003). Carvalho (2003) reports an increment rate of $14 \mathrm{~m}^{3} \mathrm{ha}^{-1}$ year $^{-1}$ and wood density of 0.70 to $0.76 \mathrm{~g} \mathrm{~cm}^{-3}$. The wood is moderately resistant to decay; durable if kept dry (Carvalho, 2003). The bole is always straight and cylindrical, used to produce long pieces for heavy construction (board, lath, sawnwood, roundwood, fuelwood (Carvalho, 2003; Coradin et al., 2011; Schuch et al., 2008).

Nectandra spp. (Lauraceae) Nees, locally known as canelas, is a group of late secondary species that includes $N$. lanceolata, $N$. oppositifolia, $N$. rigida and N. membranacea, typical species of the secondary forests of southern Atlantic Forest (Bechara et al., 2009). These species are hermaphrodite, have zoophilic pollination syndrome and zoochoric dispersion (Carvalho, 2003). These fast-growing species reach rates of increment of $10 \mathrm{~m}^{3} \mathrm{ha}^{-1}$ year $^{-1}$ (Carvalho, 2003) and densities of 0.50 to $0.60 \mathrm{~g} \mathrm{~cm}^{-3}$. The wood is moderately resistant to decay and resistant to xylophagous insects (Carvalho, 2003), except N. membranacea. The timber obtained from the straight boles are use as sawnwood, roundwood, fuelwood and furniture (Carvalho, 2003; Coradin et al., 2011).

\subsection{Data collection and analysis}

Data were collected in 17 plots $(40 \times 40 \mathrm{~m})$ randomly allocated across the contiguous forest, being 12 plots in the enriched forest and 5 in the unmanaged forest. Despite the spatial variation of specific site characteristics across the sampled forest were not assessed, the sampling plots were distributed across the entire sites, hoping that it represents the variation of altitude and soil conditions.

In each plot, all individuals (trees, shrubs, lianas, palm trees and fern trees) with diameter at breast height $(\mathrm{DBH}) \geq 5 \mathrm{~cm}$ were identified and $\mathrm{DBH}$ and commercial height (only trees) measured. From the $\mathrm{DBH}$, the individual basal area $\left(\mathrm{BA}\right.$, in $\left.\mathrm{m}^{2}\right)$ was computed, allowing us to obtain the total BA $\left(\mathrm{m}^{2} \mathrm{ha}^{-1}\right)$. In addition, the volume of commercial timber was calculated for trees with $\mathrm{DBH} \geq 15 \mathrm{~cm}$, using the equation $V=B A_{d b h} \times \mathrm{H} \times a$, where $B A_{d b h}$ is the basal area $\left(\mathrm{m}^{2} \mathrm{ha}^{-1}\right)$ at $\mathrm{DBH}$ height, $H$ is the bole height $(\mathrm{m})$, and $\alpha$ is the stem form, set as 0.6 in this study. The total timber volume $\left(\mathrm{m}^{3} \mathrm{ha}^{-1}\right)$ of each plot was calculated. Mean annual rate of increment of timber volume $\left(\mathrm{m}^{3} \mathrm{ha}^{-1}\right.$ year $\left.{ }^{-1}\right)$ of each plot was calculated by dividing the total timber volume by the forest age, expressing a mean linear growth rate over the 33 years of forest growth.

We first presented the data for individual trees to represent the whole structure of the forests (all individuals with $\mathrm{DBH} \geq 5 \mathrm{~cm}$ ) (Table 1). Then, to analyze the timber stock of the forests, we present the data based on tree trunks instead of individuals (Table 2), as many trees presented more than one bole. Data on timber stock was split into two size categories of trunks. The first category includes small trunks $(\mathrm{DBH} \geq 5 \mathrm{~cm}$ and $<15 \mathrm{~cm}$ ) and represents the potential commercial timber stock for harvesting in the midterm future $(15 \mathrm{~cm}$ is the minimum diameter cutting limit in the region); the second category, which includes large trunks $(\mathrm{DBH} \geq 15 \mathrm{~cm})$, represents the commercial timber stock available for harvesting now or in a short-term future.

In addition, we divided the data into three nested subclasses of species to analyze the importance of the planted species (M. cinnamomifolia, $H$. alchorneoides and Nectandra spp.) to forest structure and timber stocks in both forests, and to evaluate the impact of forest enrichment. The class all species includes all individuals comprising trees, shrubs, lianas, palms, and tree ferns. Secondly, the subclass tree species includes all commercial and non-commercial tree species. Finally, data on the three species used to enrich the forest, either individually or collectively, could 
Table 1. Forest structure (individuals of trees, shrubs, palm trees, lianas and tree ferns with Diameter at Breast Hight $(\mathrm{DBH}) \geq 5 \mathrm{~cm}$ ) of the enriched and control forests at the age of 33 years ${ }^{1}$. Data for the three species used in the enrichment of the forest are presented individually.

\begin{tabular}{|c|c|c|c|c|}
\hline \multirow{3}{*}{ Species } & \multicolumn{2}{|c|}{ Enriched forest } & \multicolumn{2}{|c|}{ Control forest } \\
\hline & Density & Basal area & Density & Basal area \\
\hline & (individuals $\mathrm{ha}^{-1}$ ) & $\left(\mathrm{m}^{2} \mathrm{ha}^{-1}\right)$ & (individuals ha ${ }^{-1}$ ) & $\left(\mathrm{m}^{2} \mathrm{ha}^{-1}\right)$ \\
\hline All species & $1,439 \mathrm{~ns}^{\mathrm{t}}$ & $29.4 \mathrm{~ns}^{\mathrm{t}}$ & $1,683 \mathrm{~ns}$ & $26.8 \mathrm{~ns}$ \\
\hline Tree species & $984 \mathrm{~ns}^{\mathrm{t}}$ & $26.9 \mathrm{~ns}^{\mathrm{t}}$ & $1,189 \mathrm{~ns}$ & $23.8 \mathrm{~ns}$ \\
\hline M. cinnamomifolia & 34 & 1.7 & 46 & 1.1 \\
\hline H. alchorneoides & 166 & 7.6 & 161 & 4.3 \\
\hline Nectandra spp. & 150 & 4.3 & 81 & 1.9 \\
\hline Subtotal & $350 n s^{t}$ & $13.7 \mathrm{a}^{\mathrm{w}}$ & $289 \mathrm{~ns}$ & $7.4 \mathrm{~b}$ \\
\hline Other tree species & 634 & 13.2 & 900 & 16.5 \\
\hline
\end{tabular}

${ }^{1}$ Different letters in the same row indicate significant statistical difference $(\mathrm{p}<0.05)$ between enriched and control forests; ns = non significant difference. Only comparisons with letters assigned were tested. ${ }^{\mathrm{t}} \mathrm{t}$-test. "Welch test.

Table 2. Forest structure and timber stocks of tree species from the enriched and the control secondary forest at the age of 33 years $^{1}$, by classes of Diameter at Breast Hight (DBH).

\begin{tabular}{|c|c|c|c|c|}
\hline \multirow{2}{*}{ Species } & Number & Basal area & Commercial & Timber volume \\
\hline & $\mathbf{h a}^{-1}$ & $\left(\mathrm{~m}^{2} \mathrm{ha}^{-1}\right)$ & height (m) & $\left(\mathrm{m}^{3} \mathbf{h a}^{-1}\right)$ \\
\hline \multicolumn{5}{|l|}{ Enriched forest } \\
\hline \multicolumn{5}{|c|}{ Trunks, $5 \mathrm{~cm} \leq \mathrm{DBH}<15 \mathrm{~cm}$} \\
\hline M. cinnamomifolia & 3 & 0.1 & - & - \\
\hline H. alchorneoides & 55 & 0.5 & - & - \\
\hline Nectandra spp. & 89 & 0.6 & - & - \\
\hline Subtotal & $147 n s^{t}$ & $1.2 \mathrm{~ns}^{\mathrm{w}}$ & - & - \\
\hline Other species & 604 & 4.1 & - & - \\
\hline Total/Average & $751 \mathrm{~b}^{\mathrm{t}}$ & $5.3 \mathrm{~ns}^{\mathrm{w}}$ & - & - \\
\hline \multicolumn{5}{|l|}{ Trunks, $\mathrm{DBH} \geq 15 \mathrm{~cm}$} \\
\hline M. cinammomifolia & 31 & 1.7 & 10.0 & 10.3 \\
\hline H. alchorneiodes & 130 & 7,5 & 8.1 & 38.2 \\
\hline Nectandra spp. & 82 & 4.1 & 8.5 & 21.3 \\
\hline Subtotal & $243 \mathrm{a}^{\mathrm{t}}$ & $13.2 \mathrm{a}^{\mathrm{t}}$ & 8.5 & $69.8 \mathrm{a}^{\mathrm{t}}$ \\
\hline Other species & 153 & 8.3 & 7.0 & 34.3 \\
\hline Total/Average & $396 \mathrm{~ns}^{\mathrm{w}}$ & $21.5 \mathrm{a}^{\mathrm{t}}$ & 7.8 & $104.1 \mathrm{~ns}^{\mathrm{t}}$ \\
\hline \multicolumn{5}{|l|}{ Control forest } \\
\hline \multicolumn{5}{|c|}{ Trunks, $5 \mathrm{~cm} \leq \mathrm{DBH}<15 \mathrm{~cm}$} \\
\hline M. cinammomifolia & 28 & 0.3 & - & - \\
\hline H. alchorneiodes & 80 & 0.8 & - & - \\
\hline Nectandra spp. & 53 & 0.4 & - & - \\
\hline Subtotal & $160 \mathrm{~ns}$ & $1.5 \mathrm{~ns}$ & - & - \\
\hline Other species & 1,068 & 7.3 & & - \\
\hline Total/Average & 1,228 a & $8.8 \mathrm{~ns}$ & - & - \\
\hline \multicolumn{5}{|l|}{ Trunks, $\mathrm{DBH} \geq 15 \mathrm{~cm}$} \\
\hline M. cinammomifolia & 19 & 0.4 & 10.6 & 5.4 \\
\hline H. alchorneiodes & 84 & 3.7 & 8.9 & 20.5 \\
\hline Nectandra spp. & 29 & 1.5 & 9.9 & 9.1 \\
\hline Subtotal & $131 \mathrm{~b}$ & $5.6 \mathrm{~b}$ & 9.4 & $35.1 \mathrm{~b}$ \\
\hline Other species & 242 & 8.8 & 8.2 & 43.3 \\
\hline Total/Average & $374 \mathrm{~ns}$ & $14.9 \mathrm{~b}$ & 8.7 & $78.4 \mathrm{~ns}$ \\
\hline
\end{tabular}

${ }^{1}$ Different letters indicate significant statistical difference $(\mathrm{p}<0.05)$ between enriched and control forests; $\mathrm{ns}=$ no significant difference. Only comparisons with letters assigned were tested. ${ }^{t} \mathrm{t}$-test. "Welch test. 
therefore be discerned from the remaining species, or from the overall mean across all species. With the same purpose, data on trunks of these species are presented individually to analyze timber stocks in response to forest management (Table 2).

We compared the forest structure (density and basal area) between the enriched and the unmanaged forest regarding the total number of individuals (all species) and the pooled individuals of M. cinnamomifolia, H. alchorneoides and Nectandra spp. Forest structure (number of trunks and basal area) of the enriched versus unmanaged forests was also compared regarding small and large trunks of all tree species and the pooled trunks of M. cinnamomifolia, H. alchorneoides and Nectandra spp. In addition, we assessed the impact of forest enrichment and the slashing of competing regeneration on the timber stock (trunks with $\mathrm{DBH} \geq 15 \mathrm{~cm}$ ) of all tree species as well as the pooled M. cinnamomifolia, H. alchorneoides and Nectandra spp. All these variables were expressed as per hectare.

For all comparisons we used the t-test when variance of data was homogeneous; otherwise, the Welch test was used. The test type was indicated by the symbols $t$ and $w$, respectively.

\section{RESULTS AND DISCUSSION}

\subsection{Forest composition and structure}

A total of 146 species was found in the 17 plots sampled (about $2 \mathrm{ha}$ ) in the enriched forest, including important commercial species like Cabralea canjerana, Cedrela fissilis, Citharexylum myrianthum, Cupania vernalis, Matayba intermedia, Miconia cabucu, Talauma ovata, Trichilia lepidota, Virola bicuhyba, and Xylopia brasiliensis.

The total density and basal area of all species (trees, shrubs, palms, lianas, tree ferns) in the enriched forest and unmanaged forest did not differ statistically (Table 1$)(\mathrm{t}=1.473, \mathrm{df}=15, \mathrm{p}=0.162$, and $\mathrm{t}=0.952, \mathrm{df}=15, \mathrm{p}=0.356$, respectively, for density and basal area). The density and basal area of tree species were also similar in both forests, $(t=1.226$, $\mathrm{df}=15, \mathrm{p}=0.239$, and $\mathrm{t}=1.057, \mathrm{df}=15, \mathrm{p}=0.307$, respectively). Regarding the species planted in the enriched forest ( $M$. cinnamomifolia, H. alchorneoides and Nectandra spp.), the density was similar in the two forests (350 and 289 individuals ha ${ }^{-1}$, respectively) $(\mathrm{t}=1.179, \mathrm{df}=15, \mathrm{p}=0.257)$ but the basal area of the enriched forest $\left(13.7 \mathrm{~m}^{2} \mathrm{ha}^{-1}\right)$ was almost twice as high as the basal area of the unmanaged forest $\left(7.4 \mathrm{~m}^{2} \mathrm{ha}^{-1}\right)$ $(\mathrm{t}=3.184 ; \mathrm{df}=15 ; \mathrm{p}=0.006)($ Table 1$)$.

Despite the managed forest was enriched with seedlings of M. cinnamomifolia, H. alchorneoides and Nectandra spp. at the beginning of the successional process, and despite the control of regeneration of undesired species applied to this forest over the first five years of growth, they presented similar structure. The 28-years period the managed forest was left untended since then was long enough for the establishment of a large number of new individuals, making this forest structurally resemble to the unmanaged forest.

The two forests did not differ statistically in terms of basal area possibly because at the age of 33 years they already attained a basal area close to the limit for the site. Similar basal area has been reported for secondary forests in the region (Vibrans et al., 2012). While it is possible that the basal area of the two forests will further increase, we believe that increment rates will be low. This because other studies have shown that basal area of young successional forests grows exponentially, reaching high values within two or three decades after the succession initiates, and then slow down significantly (Piotto et al., 2009; Peña-Claros, 2003). Regarding the pool of M. cinnamomifolia, H. alchorneoides and Nectandra spp., although the early forest treatment did not affect their density, it induced a higher DBH growth, which was reflected in a higher basal area of these species, possibly due to the slashing of the competing regenerating trees during the first five years.

We cannot assess the exact survival, recruitment and mortality rates of the planted species because seedlings were not individually tagged. In the case of M. cinnamomifolia, the 34 trees per hectare found (Table 1 ) were only $3.6 \%$ of the number of seedlings planted in the enriched forest and this rate could be even lower considering that some of these trees may as well have originated from natural regeneration. While it is one of the most common species in secondary forests of the region, low survival rates in open land and under a closed canopy (Carvalho, 2003) have been reported. As M. cinnamomifolia, the density of H. alchorneoides (166 trees per hectare) found in the enriched forest was also much lower than the number 
of seedlings planted. Low survival rates for this species have also been reported by Piotto et al. (2003b) in mixed (51.5\%) and pure (29.5\%) plantations in Costa Rica. Low quality of seedlings and poor planting techniques may have contributed to low success of the forest enrichment. The DBH distribution of both species in the enriched forest is close to a left-skewed unimodal distribution, typical of even-aged cohorts (Figure 2). The low proportion of small trees is evident, especially when compared to the unmanaged forest.

The DBH distribution of Nectandra spp. across size classes is closer to a reverse-J curve in both forests types (Figure 2), typical of a late succession species (Bechara et al., 2009). As the forest developed 28 years without intervention, many of the individuals existing in the enriched forest might have regenerated spontaneously, from seeds arriving from neighboring vegetation. As a consequence, the higher number of trees in almost all size classes in the enriched forest cannot be surely attributed to the planting of seedlings nor the tending of this forest.

Forest structure of tree species of both forests was also compared by analyzing data on trunks instead of individuals. The total number of small trunks $(5 \mathrm{~cm} \leq \mathrm{DBH}<15 \mathrm{~cm}$ ) in the enriched forest (751 trunks $\mathrm{ha}^{-1}$ ) was significantly lower than in the unmanaged forest $(\mathrm{t}=2.132 ; \mathrm{df}=15 ; \mathrm{p}=0.049)$ (Table 2). This result may reflect the impact of the selective slashing of undesired species during the first five years in the enriched forest, mainly those with multiple boles. On the other hand, there was no significant difference in basal area of small trunks $(\mathrm{t}=1.522 ; \mathrm{df}=4.40 ; \mathrm{p}=0.196)$. The total number of trunks and the basal area of the M. cinnamomifolia, H. alchorneoides and Nectandra spp. together also did not differ significantly between the two forest types (Table 2).

Differences between the two forests were evident when analyzing their structure regarding the largest trunks $(\mathrm{DBH} \geq 15 \mathrm{~cm})$. Although the total number of large trunks was similar in both forests $(t=0.505$; $\mathrm{df}=10.27 ; \mathrm{p}=0.624)$, their basal area in the enriched forest was $44 \%$ higher compared to the unmanaged forest $(\mathrm{t}=2.644 ; \mathrm{df}=15 ; \mathrm{p}=0.018)$ (Table 2). Considering only $M$. cinnamomifolia, $H$. alchorneoides and Nectandra spp., the number of trunks per hectare was $85 \%$ higher in the enriched forest compared to the unmanaged forest $(\mathrm{t}=2.741 ; \mathrm{df}=15 ; \mathrm{p}=0.015)$, while the basal area was $135 \%$ higher $(t=2.645 ; \mathrm{df}=15$; $\mathrm{p}=0.018)$ (Table 2). In addition, while in the enriched forest the number and the basal area of large trunks per hectare of these species represented about $61 \%$ of the total values for these variables, in the unmanaged forest they represent only $35 \%$ and $38 \%$, respectively. These results reveal that although the management practices applied to the enriched forest were not guided by technical recommendations from research work, they significantly improved timber production.

\subsection{Timber productivity and opportunities for management}

The timber volume of tree species with $\mathrm{DBH} \geq 15 \mathrm{~cm}$ in the enriched forest $\left(104.1 \mathrm{~m}^{3} \mathrm{ha}^{-1}\right)$ was not statistically different from the volume found in the unmanaged

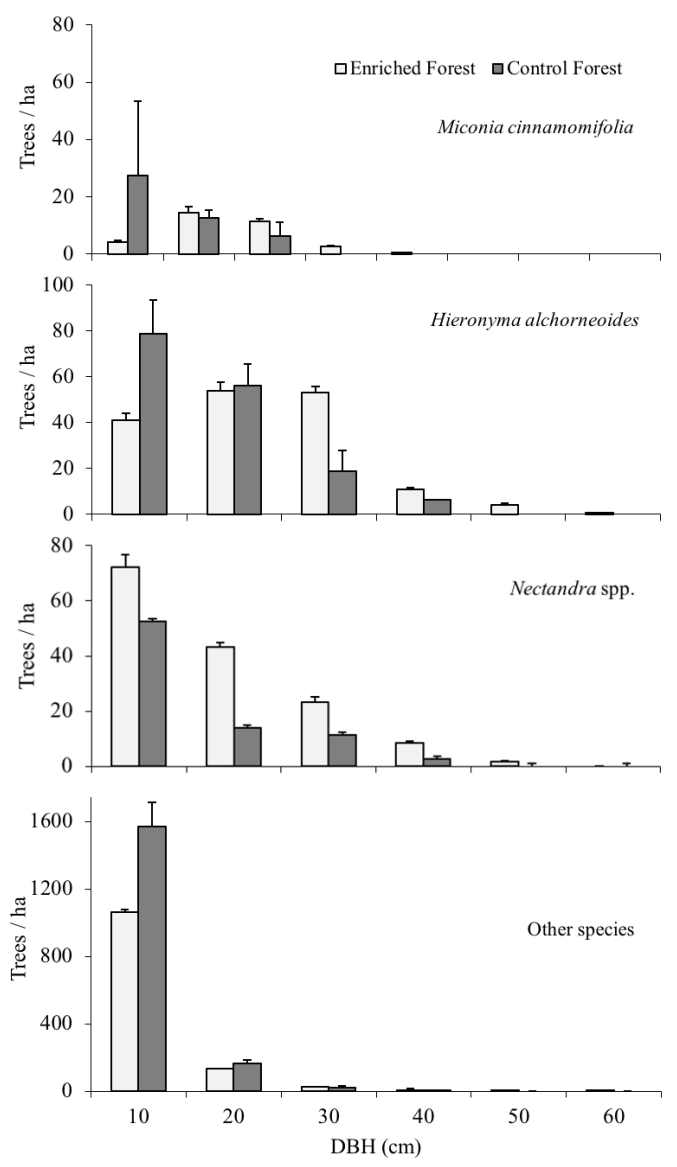

Figure 2. DBH distribution of woody species $(\mathrm{DBH} \geq 5 \mathrm{~cm})$ in the enriched and control forest, at the age of 33 years (bars represent standard error of the mean). 
forest $\left(78.4 \mathrm{~m}^{3} \mathrm{ha}^{-1}\right)(\mathrm{t}=2.049 ; \mathrm{df}=15 ; \mathrm{p}=0.006)$ (Table 2). However, when we look only at the timber volume of $M$. cinnamomifolia, $H$. alchorneoides and Nectandra spp., the stock in the enriched forest $\left(69.8 \mathrm{~m}^{3} / \mathrm{ha}\right)$ was twice as high as the volume in the unmanaged forest $\left(35.1 \mathrm{~m}^{3} / \mathrm{ha}\right)(\mathrm{t}=4.020$; $\mathrm{df}=15$; $\mathrm{p}=0.001$ ), a difference resulting from the combination of a greater number of trunks and greater basal area in the enriched forest.

The overall productivity of the enriched forest $\left(3.7 \mathrm{~m}^{3} \mathrm{ha}^{-1}\right.$ year-1) and the unmanaged forest $\left(2.4 \mathrm{~m}^{3} \mathrm{ha}^{-1}\right.$ year $\left.^{-1}\right)$ reveals the potential for boosting productivity by management, even though no silvicultural treatments were applied to enhance the growth of commercial species. Liberation and release cuttings and pruning, for example, are expected to increase productivity and quality of timber in secondary forests (Guariguata, 1999; Mesquita, 2000). Finegan (1992) reported a growth rate of $6.2 \mathrm{~m}^{3} \mathrm{ha}^{-1}$ year-1 achieved through the management of a secondary forest in Trinidad, arguing that this result revealed, "the most productive tropical lowland rain forest yet managed". Other studies have shown the success of silvicultural interventions at early ages of forest development aiming to increase increment rates of mixed plantations and secondary forests alike (Sears et al., 2014). For example, Carvalho (2003) reports productivities of 10 to $15 \mathrm{~m}^{3} \mathrm{ha}^{-1}$ year $^{-1}$ at the age of 9 to 15 years in even-aged trial plots of M. cinnamomifolia and N. lanceolata, respectively, which is much higher than the mean rates of increment found in our study. However, this might also be due to the possibility that the trees in our study have already passed their maximum growth rate and may be slowing growth by their sampled age of 33 years.

Despite the production potential of these forests, landowners typically compare these growth rates with those of even-aged forests of the non-native Pinus and Eucalyptus species, which can reach up to $36 \mathrm{~m}^{3} \mathrm{ha}^{-1}$ year ${ }^{-1}$ and $40 \mathrm{~m}^{3} \mathrm{ha}^{-1}$ year ${ }^{-1}$ at the age 15 and 7 years, respectively. Not even state of the art plantation of native species can beat such productivities. Not surprisingly, Pinus and Eucalyptus plantations are not only the preferred species for reforestation, occupying more than 6 million hectares in Brazil, but have also increasingly replaced natural vegetation, either forests or native grasslands, in the Atlantic Forest region (Fantini et al., 2017; Siminski \& Fantini, 2010). The preference for the quick and large returns with exotic species, as well as environmental regulations, lack of incentives, rudimentary technology and production chains for reforesting with native trees and for managing secondary forests are now part of a vicious circle of negative feedbacks that results in conversion of natural forests to exotic monoculture plantations (Fantini et al., 2017).

In our study, a meaningful interpretation of the results should take into account that the forest remained untended for most of its growing period, resulting in a highly uneven-aged ecosystem, regardless of whether or not this outcome was intended by the landowner. This interpretation suggests that its management should take advantage of the large number of trees regenerated spontaneously; many of them will possibly become available for exploitation in successive harvesting cycles, shorter than the first cycle. Relying on natural regeneration would also incorporate the advantage of avoiding the costs of planting seedlings (Fantini \& Siminski, 2016).

In the enriched forest, $70 \mathrm{~m}^{3} \mathrm{ha}^{-1}$ ( $67 \%$ of the total volume) of large trunks came from planted species, M. cinnamomifolia, H. alchorneoides and Nectandra spp., while in the unmanaged forest the volume of these species $\left(35.1 \mathrm{~m}^{3} \mathrm{ha}^{-1}\right)$ represents $45 \%$ of the total volume of large trunks (Table 2). These species reach among the highest market value of fast-growing native species from the Atlantic Forests. The fact that they have been chosen to enrich the young forest suggests that the landowners were aware of an existing market for timber of fast-growing native species.

In both forests, $H$. alchorneoides comprises the greatest volume of timber: $38.2 \mathrm{~m}^{3} \mathrm{ha}^{-1}$ in the enriched forest and $20.5 \mathrm{~m}^{3} \mathrm{ha}^{-1}$ in the unmanaged forest, representing $37 \%$ and $26 \%$ of the total volume of trunks, respectively (Table 2). In addition to being one of the most common species in the secondary forests all across the southern Atlantic Forest, $H$. alchorneoides sprouts well from stumps and its durable timber attains attractive selling prices. The species occurs over a vast area of the South and Central America, which suggests that it is adaptable to a wide range of environmental conditions. All these characteristics, rarely combined in a single species, make $H$. alchorneoides a species with high potential for timber production in secondary forests.

Nectandra spp. also comprise a significant proportion of the total volume in both forests $(21 \%$ and $12 \%$ in the enriched and unmanaged forest, respectively) (Table 2) 
and produce good timber, especially N. oppositifolia. Although it was a dominant species in a few plots in the studied area, on average, $M$. cinnamomifolia reached volumes below the expected values, as it is a dominant species in many mid successional forests (Lingner et al., 2015), reaching densities up to 1,100 trees per hectare.

The harvest of the mature individuals of the M. cinnamomifolia, H. alchorneoides or N. lanceolata should take into account their ecological characteristics. For example, the trees of $M$. cinnamomifolia and Nectandra membranacea are virtually even-aged and mature at 30 years of age such that they could be harvested at once. Many individuals of $H$. alchorneoides could also be harvested in the first intervention in order to open the canopy to the desired level. On the other hand, some species of Nectandra, like N. oppositifolia, as late successional species, should be managed under a polycyclic harvesting regime. Unfortunately, there are no data available on the growth rates of such managed forest in the region. Because the forest is at a mid to late succession stage, the harvesting intensity and the consequent gap size will determine whether the ecosystem will be rejuvenated to an early or mid-secondary forest. While the larger openings will probably favor fast-growing species, and consequently increase forest productivity, smaller gaps will produce more valuable timber from species that grow relatively more slowly. The optimum turning point of this tradeoff is yet to be evaluated, mainly considering possible simultaneous economic returns from other ecosystem services provided by both scenarios.

Although the timber volume in the enriched forest was higher than in the unmanaged forest, the potential net economic return from commercial timber in the unmanaged forest should not be underestimated, because it incurs no establishment costs in contrast with planting and tending expenses in enriched or planted forests. Most of these forests are located on small farms, representing an important asset for their owners, readily available for management. In the presence of adequate legislation and/or incentives, the prospect of income from timber could stimulate these land owners to conserve their remnant forests, encourage regeneration, and prevent forest conversion to other land uses or to plantations with monocultures of exotic tree species, an option spreading widely throughout the region (Fantini et al., 2017; Siminski \& Fantini, 2010).

\section{CONCLUSIONS}

The fast-growing $M$. cinnamomifolia, $H$. alchorneoides and Nectandra spp., native species with the greatest potential for timber production, represented the main volume ready for harvesting at 33 years of age in both the enriched and the unmanaged forest. Our findings also signal the productivity-enhancing potential of planting and tending widespread fast-growing species in managed secondary forests, mixed plantations and agroforestry systems. Our results suggest that small-scale management of secondary forest has potential to produce sufficient merchantable timber to become an incentive for land owners to maintain and recover forest on their farms, thereby avoiding conversion to biodiversity-poor land uses, provided that there are legal provisions for sustainable management. Future studies should analyze the economic feasibility and possible ecological tradeoffs of different strategies and intensities of sustainable secondary forest and agroforest management for timber and other uses.

\section{ACKNOWLEDGEMENTS}

We thank the landowners of the study site for their support and for providing us important information on local forest history. FATMA is a partner institution in the development of our studies on potential uses of secondary forests. CNPq (Grant 304351/2015-6) and FAPESC (Grant 18.689/2009-9) funded this study through financial support and scholarships. Two anonymous reviewers are gratefully acknowledged for constructive comments.

\section{SUBMISSION STATUS}

Received: 6 jun., 2017

Accepted: 3 aug., 2018

\section{CORRESPONDENCE TO}

\section{Alfredo Celso Fantini}

Departamento de Fitotecnia, Universidade

Federal de Santa Catarina - UFSC, Rodovia

Admar Gonzaga, 1346, CEP 88034-000,

Florianopolis, SC, Brasil

e-mail: alfredo.fantini@ufsc.br 


\section{FINANCIAL SUPPORT}

Conselho Nacional de Desenvolvimento Científico e Tecnológico (Grant / Award Number: 304351/2015-6), Fundação de Amparo à Pesquisa e Inovação do Estado de Santa Catarina (Grant / Award Number: 18.689/2009-9)

\section{REFERENCES}

Adams C, Munari LC, Van Vliet N, Murrieta RSS, Piperata BA, Futemma $\mathrm{C}$ et al. Diversifying Incomes and Losing Landscape Complexity in Quilombola Shifting Cultivation Communities of the Atlantic Rainforest (Brazil). Human Ecology 2013; 41(1): 119-137. http://dx.doi.org/10.1007/ s10745-012-9529-9.

Alarcon GG, Caporal DS, Beltrame AV, Karam KF. Transformação da paisagem e uso dos recursos florestais na agricultura familiar: um estudo de caso em área de Mata Atlântica. Ciência Florestal 2011; 21(2): 369-380. http://dx.doi.org/10.5902/198050983242.

Bechara FC, Tiepo EN, Reis A. Contribuição ao manejo sustentável do complexo ferruginoso Nectandra na Floresta Nacional de Ibirama SC. Revista Árvore 2009; 33(1): 125 132. http://dx.doi.org/10.1590/S0100-67622009000100013.

Carvalho PER. Espécies arbóreas. vol. 1. Colombo: Embrapa: CNPF; 2003.

Coradin L, Siminski A, Reis A. Espécies nativas da flora brasileira de valor econômico atual ou potencial: plantas para o futuro - Região Sul. Brasília: MMA; 2011.

Fantini AC, Bauer E, Valois CM, Siddique I. The demise of swidden-fallow agriculture in an Atlantic Rainforest region: Implications for farmers' livelihood and Conservation. Land Use Policy 2017; 69: 417-426. http://dx.doi.org/10.1016/j. landusepol.2017.09.039.

Fantini AC, Siminski A. Manejo de florestas secundárias da Mata Atlântica para produção de madeira: possível e desejável. Revista Brasileira de Pós-Graduação 2016; 13(32): 673-698.

Finegan B. The management potential of Neotropical secondary lowland rain forest. Forest Ecology and Management 1992; 47(2): 295-321. http://dx.doi.org/10.1016/03781127(92)90281-D.

Fundação SOS Mata Atlântica e o Instituto Nacional de Pesquisas Espaciais - INPE. Atlas dos remanescente florestais da Mata Atlântica período 2012-2013: relatório técnico [online] São Paulo: Fundação SOS Mata Atlântica; 2014 [cited 2017 Mar 28]. 86 p. Available from: http://mapas. sosma.org.br/site_media/download/atlas_2012-2013_ relatorio_tecnico_2014.pdf

Guariguata MR. Early response of selected tree species to liberation thinning in a young secondary forest in
Northeastern Costa Rica. Forest Ecology and Management 1999; 124(2-3): 255-261. http://dx.doi.org/10.1016/S03781127(99)00072-9.

Klein RM. Ecologia da flora e vegetação do Vale do Itajaí. Sellowia 1980; 32(32): 164-369.

Lingner DV, Schorn LA, Sevegnani L et al. Floresta Ombrófila Densa de Santa Catarina - Brasil: agrupamento e ordenação baseados em amostragem sistemática. Ciência Florestal 2015; 25(4): 933-946. http://dx.doi. org/10.5902/1980509820595.

Lira PK, Tambosi LR, Ewers RM, Metzger JP. Land-use and land-cover change in Atlantic Forest Landscapes. Forest Ecology and Management 2012; 278: 80-89. http:// dx.doi.org/10.1016/j.foreco.2012.05.008.

Mesquita RCG. Management of advanced regeneration in secondary forests of the Brazilian Amazon. Forest Ecology and Management 2000; 130(1-3): 131-140. http://dx.doi. org/10.1016/S0378-1127(99)00174-7.

Metzger JP. Conservation issues in the Brazilian Atlantic forest. Biological Conservation 2009; 142(6): 1138-1140. http://dx.doi.org/10.1016/j.biocon.2008.10.012.

Mukul SA, Herbohn J. The impacts of shifting cultivation on secondary forests dynamics in tropics: A synthesis of the key findings and spatio temporal distribution of research. Environmental Science \& Policy 2016; 55: 167-177. http:// dx.doi.org/10.1016/j.envsci.2015.10.005.

Padoch C, Pinedo-Vasquez M. Saving slash-and-burn to save biodiversity. Biotropica 2010; 42(5): 550-552. http:// dx.doi.org/10.1111/j.1744-7429.2010.00681.x.

Pedroso-Junior NN, Murrieta RSS, Taqueda CS, Navazinas ND, Ruivo AP, Bernardo DV et al. A casa e a roça: socioeconomia, demografia e agricultura em populações quilombolas do Vale do Ribeira, São Paulo, Brasil. Boletim do Museu Paraense Emílio Goeldi. Antropologia 2008; 3(2): 227-252. http://dx.doi.org/10.1590/S198181222008000200007 .

Peña-Claros M. Changes in forest structure and species composition during secondary forest succession in the Bolivian Amazon. Biotropica 2003; 35(4): 450-461. http:// dx.doi.org/10.1111/j.1744-7429.2003.tb00602.x.

Piotto D, Montagnini F, Thomas W, Ashton M, Oliver C. Forest recovery after swidden cultivation across a 40-year chronosequence in the Atlantic forest of southern Bahia, Brazil. Plant Ecology 2009; 205(2): 261-272. http://dx.doi. org/10.1007/s11258-009-9615-2.

Piotto D, Montagnini F, Ugalde L, Kanninen M. Performance of forest plantations in small and medium-sized farms in the Atlantic lowlands of Costa Rica. Forest Ecology and Management 2003a; 175(1): 195-204. http://dx.doi. org/10.1016/S0378-1127(02)00127-5.

Piotto D, Montagnini F, Ugalde L, Kanninen M. Growth and effects of thinning of mixed and pure plantations with native trees in humid tropical Costa Rica. Forest Ecology 
and Management 2003b; 177(1): 427-439. http://dx.doi. org/10.1016/S0378-1127(02)00445-0.

Ribeiro MC, Metzger JP, Martensen AC, Ponzoni FJ, Hirota MM. The Brazilian Atlantic Forest: How much is left, and how is the remaining forest distributed? Implications for conservation. Biological Conservation 2009; 142(6): 1141-1153. http://dx.doi.org/10.1016/j. biocon.2009.02.021.

Schorn LA, Galvão F. Dinâmica da regeneração natural em três estágios sucessionais de uma floresta ombrófila densa em Blumenau, SC. Floresta 2006; 36(1): 59-74. http://dx.doi.org/10.5380/rf.v36i1.5508.

Schuch C, Siminski A, Fantini AC. Usos e potencial madeireiro do jacatirão-açu (Miconia cinnamomifolia (De Candolle) Naudin) no litoral de Santa Catarina. Floresta 2008; 38(4): 735-741. http://dx.doi.org/10.5380/ rf.v38i4.13169.

Sears R, Cronkleton P, del Arco MPO, Robiglio V, Putzel L, Cornelius J. Timber production in smallholder agroforestry systems: justifications for pro-poor forest policy in Peru. Bogor: CIFOR; 2014.

Siminski A, Fantini AC. A Mata Atlântica cede lugar a outros usos da terra em Santa Catarina, Brasil. Biotemas 2010; 23(2): 51-59.

Siminski A, Fantini AC, Guries RP, Ruschel A, Reis MS. Secondary forest succession in the Mata Atlântica, Brazil: floristic and phytosociological trends. ISRN Ecology 2011; 2011: 759893. http://dx.doi.org/10.5402/2011/759893.

Tabarelli M, Aguiar AV, Ribeiro MC, Metzger JP, Peres CA. Prospects for biodiversity conservation in the Atlantic Forest: Lessons from aging human-modified landscapes. Biological Conservation 2010; 143(10): 2328-2340. http:// dx.doi.org/10.1016/j.biocon.2010.02.005.

Van Vliet N, Mertz O, Heinimann A, Langanke T, Pascual U, Schmook B et al. Trends, drivers and impacts of changes in swidden cultivation in tropical forest-agriculture frontiers: a global assessment. Global Environmental Change 2012; 22(2): 418-429. http://dx.doi.org/10.1016/j. gloenvcha.2011.10.009.

Vibrans AC, Sevegnani L, Gasper AL, Müller JJV, Reis MS. Inventário Florístico Florestal de Santa Catarina: Diversidade e conservação dos remanescentes florestais. Blumenau: FURB; 2012.

Vicente NR, Fantini AC. Transformações no sistema tradicional de roça itinerante na mata atlântica do litoral sul brasileiro. Interthesis 2014; 11(2): 183-203. http:// dx.doi.org/10.5007/1807-1384.2014v11n2p183.

Wiemann MC. 2010. Characteristics and availability of commercially important woods. In: Forest Products Laboratory. Wood handbook: wood as an engineering material. Madison: United States Department of Agriculture: Forest Service. 